\section{UDC 622.673.1}

S. R. Ilin ${ }^{1}$, Cand. Sc. (Tech.), Senior Research Fellow, orcid.org/0000-0001-5211-7567, V. I. Samusya ${ }^{2}$, Dr. Sc. (Tech.), Prof., orcid.org/0000-0002-6073-9558, D. L. Kolosov ${ }^{2}$, Dr. Sc. (Tech.), Assoc. Prof., orcid.org/0000-0003-0585-5908, I. S. Ilina ${ }^{2}$, Cand. Sc. (Tech.), Assoc. Prof., orcid.org/0000-0002-4307-5171, S. S. Ilina ${ }^{2}$, Cand. Sc. (Tech.), orcid.org/0000-0002-4045-4176

\section{DOI: $10.29202 /$ nvngu/2018-5/10}

1 - Institute of Geotechnical Mechanics named by N. Poljakov of National Academy of Sciences of Ukraine, Dnipro, Ukraine, e-mail: iljin_sr@ukr.net

2 - National Mining University, Dnipro, Ukraine, e-mail: vsamusya@gmail.com; evolyuta@gmail.com

\title{
RISK-FORMING DYNAMIC PROCESSES IN UNITS OF MINE HOISTS OF VERTICAL SHAFTS
}

Purpose. Estimation of risk-forming processes in operation of hoisting machines in vertical mine shafts.

Methodology. Complex analysis of the results of theoretical research and experimental data of instrumental measurements of parameters of guide geometry, dynamic interaction of lifting vessels with shaft reinforcement, velocity diagrams of vessels, wear of reinforcement elements and deformation-strength calculations.

Findings. It is shown that dynamic processes in mine hoisting installations in operating and transition modes have a property of strong interconnectedness and cumulative strengthening of risk-forming phenomena in "lifting vessel reinforcement" systems. The cumulative effect can occur when critical processes are interrelated in different units of a hoisting machine, even under the conditions that parameters of each process do not exceed permissible limits. This significantly increases the risk of an emergency situation when vessels interact with reinforcement guides under wear conditions during long operation. The means for reducing the level of risk of spontaneous accidents are provided, which ensure an increase in operation safety of hoisting complexes.

Originality. In the paper on the basis of complex analysis of electro-mechanical processes in units of hoisting machines it is shown that the main risk-forming factors are: a non-smooth character of change of ascension velocity during the cycles of descent/ascension of vessels; load displacement in a vessel; tension imbalance of head ropes of multi-rope hoists; uneven wear of guides and buntons of reinforcement combined with local curvatures of guide profiles and disturbances in parameters of their track. In this case, the emergency dynamic state of the system can occur even when the parameters of associated processes are within permissible limits established by the current regulatory documentation.

Practical value. Obtained results make it possible to comprehensively assess a technical state of "hoisting machine - rope - vessel - reinforcement" systems during operation of mine hoists and their expert examination and to establish objective causes of emergencies and their premises, develop recommendations that prevent exceeding the permissible risk depending on operating conditions.

Keywords: mine hoist, mine shaft reinforcement, "vessel - reinforcement" system, mine shaft guides, mine rope tension

Introduction. Lifting and transporting systems are the most important link in the chain of mineral extraction. The economic efficiency of a mining complex as a whole depends on an uninterrupted and safe operation of lifting and transporting systems [1, 2]. Designs of modern machines, equipment and mechanisms of mining $[3,4]$, transport $[5,6]$, technology engineering $[7,8]$ are being continuously developed and improved in the direction of increasing the productivity, reliability, strength and energy efficiency.

Mine hoist is a complex multi-unit electromechanical system. All operating parameters of individual units are energetically linked in it. A specific form and values of parameters of operating characteristics of drive mechanisms significantly affect the character and safety of the main operating element of the complex - a mine hoisting vessel.

Problem formulation. A multi-unit and branching structure of mine hoists is a source of strong interconnection of energy-mechanical processes in the elements

(C) Ilin S. R., Samusya V. I., Kolosov D. L., Ilina I. S., Ilina S. S., 2018 of ground and shaft equipment. Increased wear of the main elements of a hoisting system, violation of design values and inconsistencies in their operating parameters that occur during long-term operation in difficult mining conditions cause uncontrollable by traditional methods and means transition of technical condition of a hoisting complex into the area of increased influence of risk-forming factors on its operation safety. Based on the analysis of theoretical and experimental data, it is necessary to identify and research the main risk-forming factors during operation of hoisting machines in conditions of operation intensity increase under conditions of significant influence of degradation processes of main and auxiliary units of hoisting equipment.

Research findings. Due to technological and structural features of hoisting systems risk-forming factors act simultaneously. Their negative disturbing influence can be summed up at some point of movement or at some part of the shaft and then a "cumulative effect" occurs. As a result, accidental destruction of mechanical elements of the system can occur spontaneously: reinforcement, lifting vessel or rope. 
Five main processes have come to the fore in the present, which independently and parallel to each other influence the emergency parameters of "vessel - reinforcement" systems and hoisting as a whole. These processes can be considered dominant in hoisting operations, since at the present stage the parametric resonance is practically eliminated due to selection of parameters of the system at a design stage.

It is traditional that in a working practice of domestic mining enterprises the area of responsibility of the Chief Engineer service is a large number of units of mechanical equipment. Ensuring its smooth operation requires constant attention and a large number of daily repair works.

At the same time, the services of the Chief Surveyor and the Chief Power Engineer are distant from failure elimination (unless the failure liquidation does not require mine surveyors or does not affect the operation of electrical equipment). Root causes of accidents are often obvious only at first glance. This is due to the fact that, when searching for them, the systematic impact and duration of negative influences are not considered on individual components of mechanical equipment that occur because of unfavorable combinations of geometric parameters and/or features of operation of power equipment.

A large curvature of the profile of guides in short sections (geometric parameter) is the main source of the percussive-cyclic dynamic influence of vessels on guides with an increased level of contact loads, premature wear and tear of guides at local sections of the shaft, and their bunton clamping elements (mechanical equipment).

When operating a shaft, the presence of sections with abrupt local curvature of the profile of guides is caused by complex mining and geological conditions. The current norms do not prohibit a significant, but smooth deviation of guides from vertical in extended sections during operation. Vessel movement safety along curved sections requires a selection of vessel velocity diagram consistent with a curvature. This is ensured by the appropriate adjustment of the hoist drive system.

An abrupt break in a diagram of a drum angular speed of a hoisting machine leads to the occurrence of vertical and horizontal oscillations of the lifting vessel on a rope and percussions along the guides at local sections of a shaft, and overloading of head rope cross-sections. Systematic repetition of such percussions during different cycles also leads to an accelerated destruction of the guides and rope wires.

Drum angular speed oscillation of the hoisting machine creates a cyclic influence on the upper end of the rope. They excite driven vertical oscillations of the vessel. Their frequencies can be in a resonance zone. In this case, over-normative cyclic overload of a suspension device occurs and premature exhaustion of its cyclic endurance limit. Excessive short-term loosening of a rope tension is also possible, leading to false triggering of mechanical parachutes and cage hanging on brake ropes $[9,10]$.

External influences affecting the safety of the "vessel - reinforcement" system are: maximum operational vertical vessel acceleration/deceleration; instant acceleration during operation; instant value of the "jerk" (a function of the first derivative by time of the lifting vessel ac- celeration); instant decelerations during emergency braking; maximum average deceleration during emergency braking; deviation of guides from a vertical on adjacent levels of reinforcement; broadening/narrowing of a guide track; absolute deviations of a thread of guides from a vertical; absolute angle of inclination of a guide in a span between the levels of reinforcement; absolute angle of rotation of a guide track in a span relatively to a vertical axis.

Processes that are the main sources of increasing the risk of emergency during the intense operation of "vessel - reinforcement" systems in domestic shafts that operated for 40 to 50 years or more are shown in Fig. 1.

It can be seen that the work of power engineer services and mine surveyors has a character of auxiliary supply for operation of the mechanical service of an enterprise.

The results of influence of each of these processes on operation safety of "vessel - reinforcement" systems are considered in more detail below. The data given was obtained during the long-term monitoring of shafts by specialized laboratories of M. S. Polyakov Institute of Geotechnical Mechanics under NAS of Ukraine and a firm "AGAT-Dnepr".

Influence of parameters of a hoisting velocity diagram. The conducted research shows that the influence of a shape and parameters of hoisting velocity diagrams makes a very significant contribution to formation of dynamic percussive loads in "vessel - reinforcement" systems [11]. Operation of a monitoring system of lifting vessel movement in a mine shaft in experimental industrial conditions confirms the research conducted above [12].

On peak sections of velocity diagrams, vertical jerks of the upper ends of ropes occur, which excite vertical and horizontal oscillations of skips with percussions of hard safety shoes on reinforcement.

Modulation of alternating jerks by a velocity controller is inevitable with manual control, and is considerably larger than with automatic smooth control. The result of measurements of contact loads shows that even with a decrease in maximum velocity value at a straight section, alternating velocity modulation causes a multiple increase of dynamic loads on the reinforcement. This proves that the law of velocity control is one of the most influential factors of growth of dynamic loads in "vessel - reinforcement" systems and the risk of an emergency situation in sections with an increased level of wear of guides and buntons or elements of their mounting.

Fig. 2 shows graphs of vertical accelerations of a cage and loads on the guides during the passage of intermediate levels with the velocity diagram. It can be seen that dynamic loads on the guides increase synchronously with a cage deceleration/acceleration.

Calculations showed that only by optimizing and smoothening the velocity diagram it is possible to achieve nearly two-times decrease in contact loads under the same conditions of vessel movement.

This creates premises for increasing the maximum hoisting velocity, limited by a criterion of reinforcement condition and reducing the cycle time while maintaining the required level of safety.

Influence of vessel skew in guides due to imbalance of rope tension with multi-rope hoisting and a load center of 


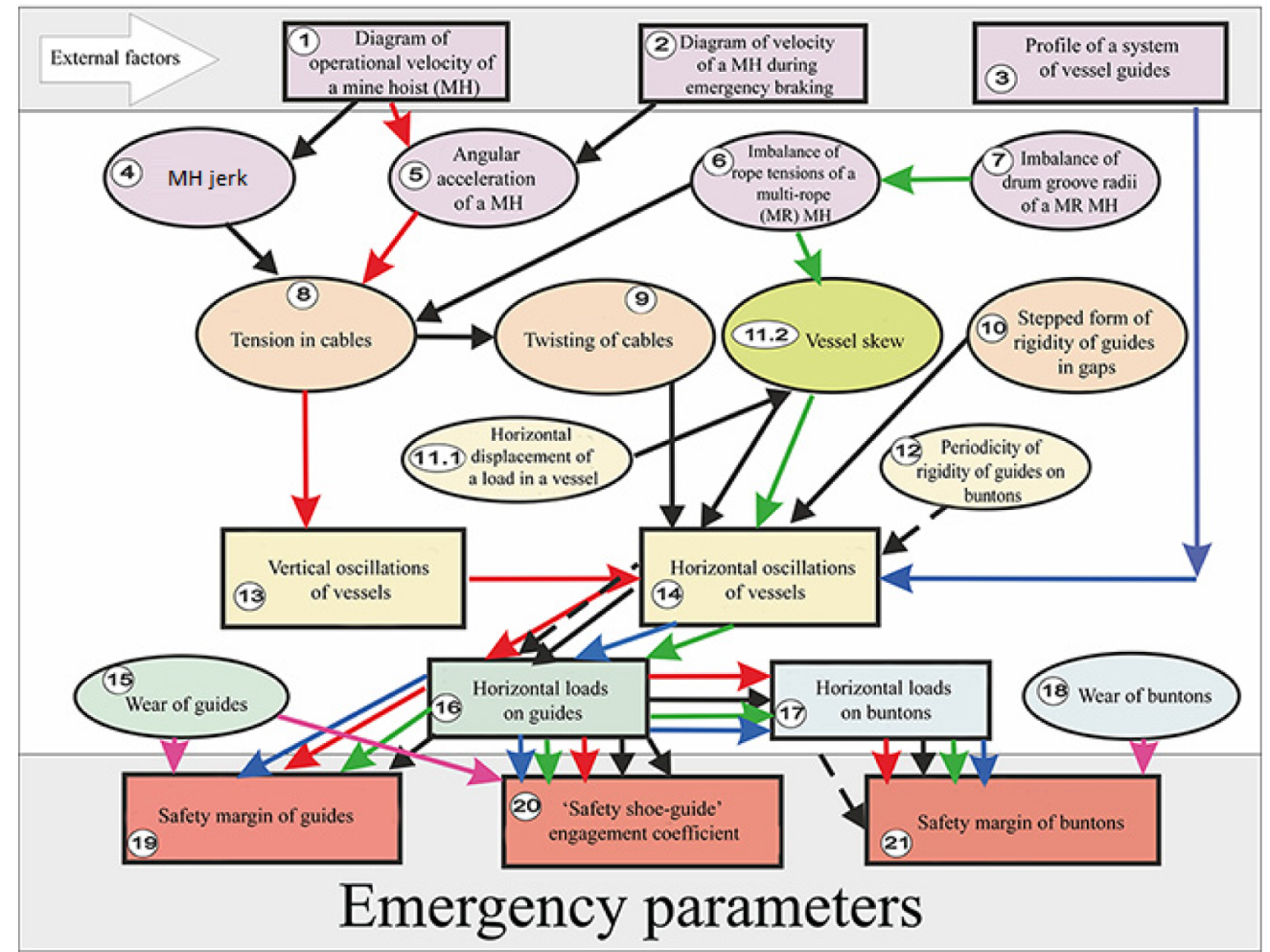

Fig. 1. Diagram of influence of units of a hoisting system on emergency parameters of "vessel - reinforcement" systems:

1 - profile of a guide system of a lifting vessel (block 3); 2 - wear of guides and buntons (block 15, block 18); 3 - shape of a diagram of the angular velocity of a hoisting machine in operating mode (in particular, presence of a polyharmonic pulsation of velocity relatively to a given diagram) and a deceleration law during activation of a safety brake (block 1, block 2); 4 - imbalance of rope tension caused by deviations of groove radii of a multi-rope hoist and rope elongation (block 6, block 7); 5 - skew of a lifting vessel caused by a load center of mass displacement from the vessel axis or by the imbalance of rope tension (block 11.1, block 11.2)

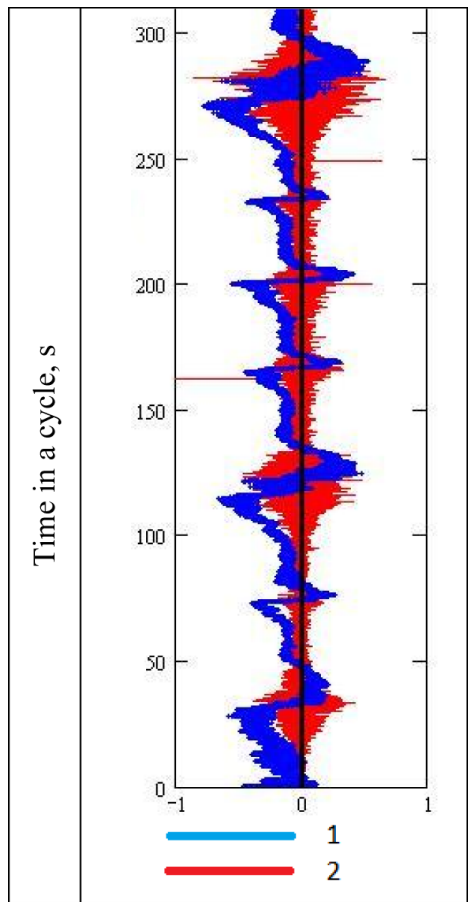

Fig. 2. Graphs of vertical cage accelerations and loads on the guides during the passage of intermediate levels at a speed of $4 \mathrm{~m} / \mathrm{s}$ :

1 - vertical acceleration $\mathrm{m} / \mathrm{s}^{2} ; 2$ - contact loads, $k N$ mass displacement on dynamic loads in the "vessel - reinforcement" system (Fig. 3). Fig. 4 shows a diagram of the influence of a load center of mass displacement on the vessel skew in the guides. Fig. 5 is a diagram of the influence of the imbalance of tension of ropes on the vessel skew in the guide track and the reduction of kinematic gaps in a "shoe-guide" pairs.

When in a skewed state, a vessel moves in a guide track in a "sliding wedge" mode, colliding by shoes with all ledges at joints of guides and local curvatures in short sections.

Vertical vessel oscillations on the elastic rope excite synchronous angular vibrations of the vessel in a track and percussions on the reinforcement. This especially manifests in a mode of safety braking. On shaft sections where frequencies of vertical and angular vessel vibrations coincide, a resonant amplification of horizontal percussions on the guides by rigid sliding shoes occurs.

As an example, a four-rope hoisting machine for a 1400-meter-deep shaft is chosen.

Calculation results of a four-rope hoist in a 1400-meter-deep shaft showed that a strain imbalance, asymmetric relatively to a skip axis is $+/-14 \%$ in the lowest position of a skip and $+/-24 \%$ in the highest causes skip wedging in the guide track, for any of the currently used roller guides.

Calculation also shows that with an accurately centered vessel, triggering of an emergency brake causes minimal percussive loads on the guides. As the eccentricity of a load increases, the loads increase up to a cer- 


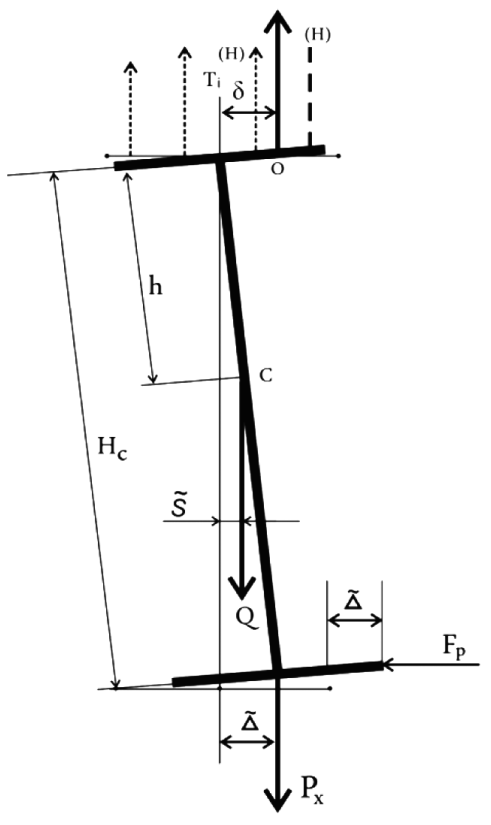

Fig. 3. Calculation scheme of influence of a load displacement (and imbalance of rope tension) to vessel skew in a guide track:

$P$ - rope tension $P=Q(1+W / g), Q-$ loaded skip weight; $W$-vertical skip acceleration, $W=A \cdot \sin (\omega t) ; b$ - loaded skip center of mass displacement; $M-$ torque, $M=P \cdot b$

tain maximum value, until a vessel comes to a wedged state at which the torque of vessel wedging in a track does not exceed the moment of inertia from center of mass displacement. With further increase in a load center of mass displacement, the loads decrease, since in this state the shoes deform the reinforcement without losing contact with it or collision.

Influence of curvature of guide profiles on dynamic loads in a "vessel - reinforcement" system. It is traditionally considered that with the same value of the maximum ascension velocity according to the diagram this

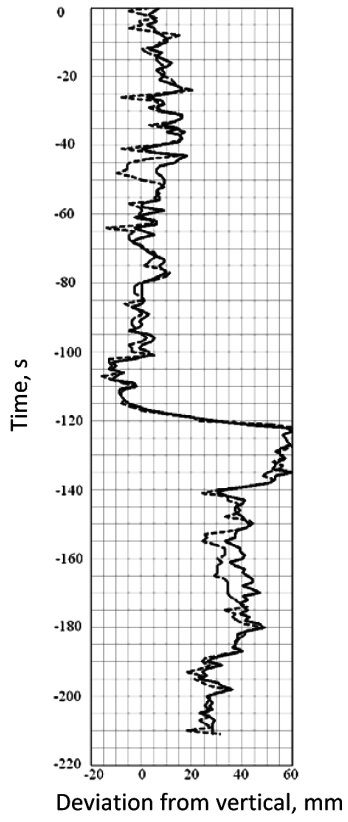

$a$

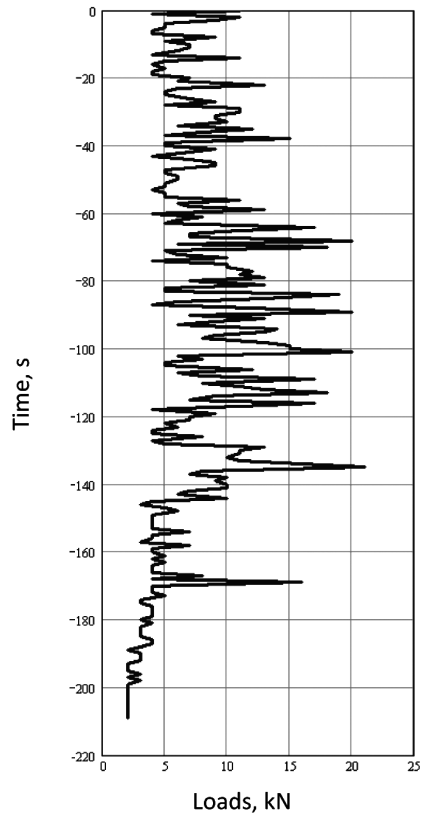

$b$
Fig. 4. Graphs of frontal profiles of guides (a) and contact loads (b) when lifting a skip

parameter has the greatest influence on the level of horizontal loads on reinforcement. Previous results have shown that this is not entirely true, although the influence of profiles is one of the most significant.

Research studies on characteristic profiles of guides that are used in most mining enterprises of Ukraine were carried out. The analysis showed that curvatures of guide profiles in shafts located in a rock shift zone and in the untouched massif are absolutely of the same level and are caused exclusively by operational reasons during 40 to 50 years of operation.

Fig. 4 shows combined graphs of frontal profiles of guides and the maximum contact loads on the reinforcement of an ore-lifting shaft.

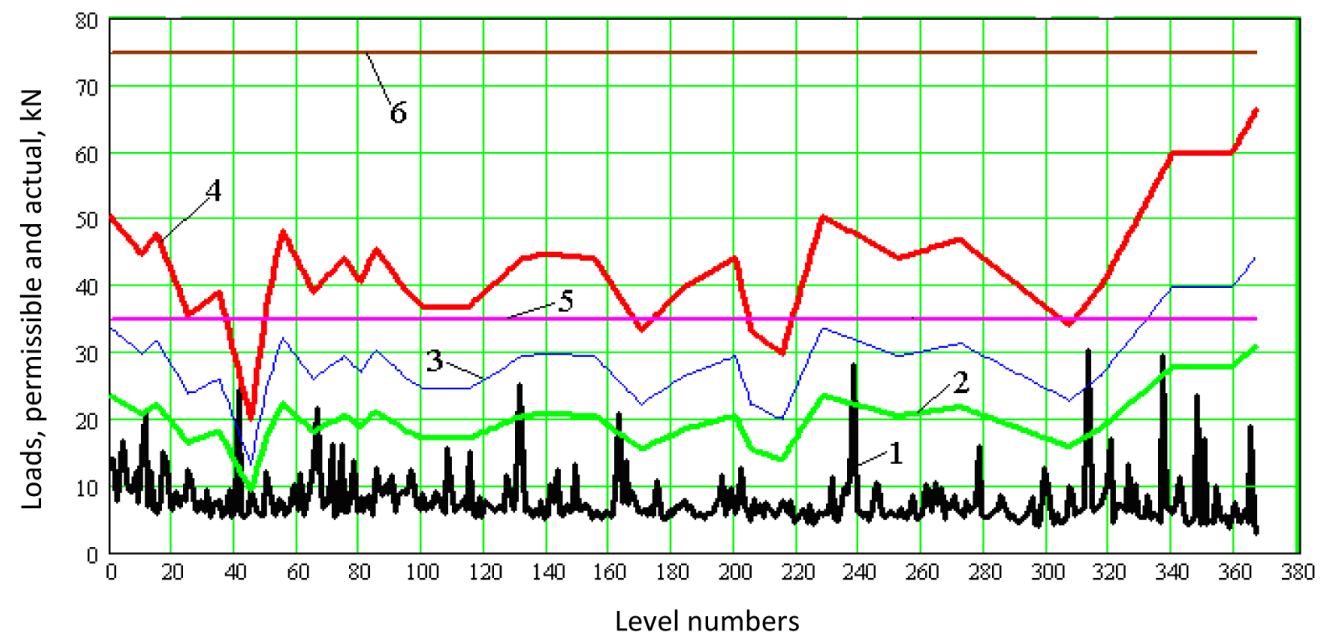

Fig. 5. Loading diagram of side buntons of a skip section of the shaft in a frontal plane of guides:

1 - actual maximum loads for all cycles of dynamic tests; 2 - permissible loads with a safety margin of 2.15; 3 - permissible loads with a safety margin of 1.5; 4 - permissible loads with a safety margin of 1.0; 5 - permissible loads with a safety margin of 2.15 for a not worn bunton; 6 - permissible loads with a safety margin of 1.0 for a unworn bunton 
It can be seen that during the process of lifting there is an active shake of a skip in a horizontal plane, while the maximum loads are applied to areas of intense local alternating curvatures of guide profiles.

It should be noted that great work done by the enterprise for over 10 years for smoothening the guide profiles in short sections, eliminating areas of increased corrosive and mechanical wear and smoothening the velocity diagrams has made it possible to significantly reduce the maximum dynamic load level on the reinforcement and increase a safe value of the maximum skip lift velocity from 8 to $11-12 \mathrm{~m} / \mathrm{s}$.

Influence of wear of guides and buntons on the emergency parameters of "vessel - reinforcement" systems.

In Fig. 5 in a layout by the reinforcement level numbers of the ore-lifting shaft, combined graphs of values of permissible loads on side buntons of a skip section are given. When they were built, the actual cross-section losses were considered. This occurred due to wear (curves 2-6), with a safety margin by yield strength of $1.0,1.5,2.15$. Also, graphs of actual operational loads are shown in the figure (curve 1).

It is seen that in places of quick loss of bearing capacity, even minor loads of about $20-30 \mathrm{kN}$ may exceed a safe level. Presented results convincingly prove that the electromechanical processes in "drive-hoisting machine ropes - vessels - reinforcement" systems are strongly interrelated. Small deviations in operating parameters of one group of operating units of the system cause large deviations in the operation of others. This is also observed in the values of safety parameters of the main unit of a hoisting machine - a "vessel - reinforcement" system.

This leads to a conclusion that minimization of the risk-creating influence of these processes on safety of hoisting operations lies in the field of maximum use of high technology within complex automation of production monitoring processes and optimal control using modern microprocessor technology in complex mining and geological conditions of operation as well as in development and application of new designs of the most risky elements of the scheme - tractive and balancing ropes of a new type [13, 14] in the existing mine hoists [15].

In Ukraine, realization of this direction is provided by a number of new means of automation and operation control of parameters of hoisting machines. These include software and hardware systems: "AKNK-DNEPR" continuous control of rope tension of a multi-rope hoisting machines and "ANKP DNEPR" - continuous control of dynamic interaction of hoisting vessels with rigid reinforcement of shafts. Their basic scheme of operation is shown in Fig. 6. Control over dynamic characteristics and processes of a wider spectrum are investigated in [16, 17]. Articles [18-20] present stability assessment of a mobile crane handling system based on a developed method with the use of built mathematical model and the model built in the integrated CAD/CAE environment.

"ANKP-DNEPR" complex provides: control of dynamic interaction of hoisting vessels with rigid reinforcement of shafts, localization at a place of ledges at joints of guides, objective control and estimation of geometrical parameters of profiles of guides of shaft rein- forcement. It provides information on operation quality of roller guides of vessels. Defects can be detected in the early stages of their development.

"ANKP-DNEPR" complex allows reducing the imbalance of rope tension during operation significantly, increasing their life cycle, reducing dynamic perturbations on hoisting vessels and contact loads on the shaft reinforcement.

An example of complex operation in a mode of monitoring the tension and issuing recommendations for correcting the radii of the multi-rope pulley grooves and the lengths of ropes is shown in Fig. 7.

A summary diagram of the operation results of AS "ANKP" complex is in Fig. 8. The following can be seen from presented oscillograms:

- "skip - reinforcement" system operates in a mode of percussive-cyclic interaction of rigid safety shoes with guides;

- the dynamic load intensity of the system in the frontal plane is approximately 3-4 times higher than in the lateral plane, and the intensity parameter "horizontal acceleration" during the descent of an empty skip is approximately 2 times higher than when ascending the loaded one;

- in the area of a shaft around 160-166 m deep when the empty skip is descending and the loaded skip is ascending, the percussion of rigid safety shoes on guides is systematically realized in a lateral plane of the guides. This indicates a violation of straightness of guides at joints;

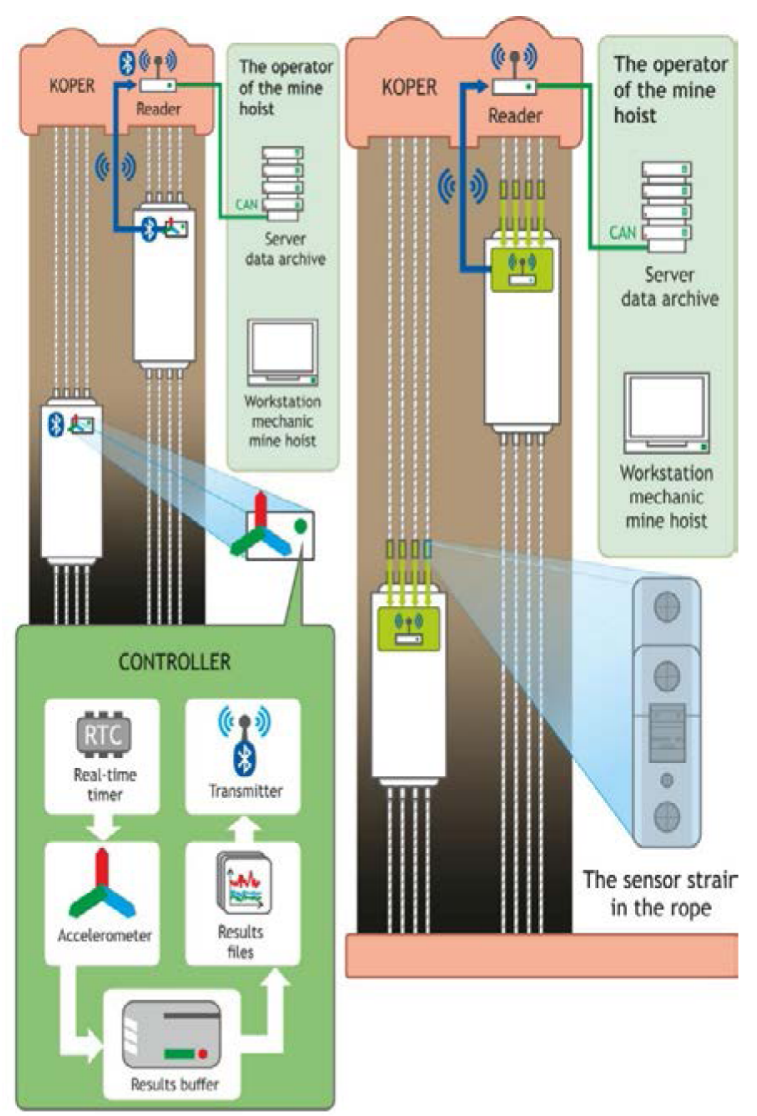

Fig. 6. Diagram of software and hardware systems for rope tension control and control of a smooth movement of hoisting vessels 


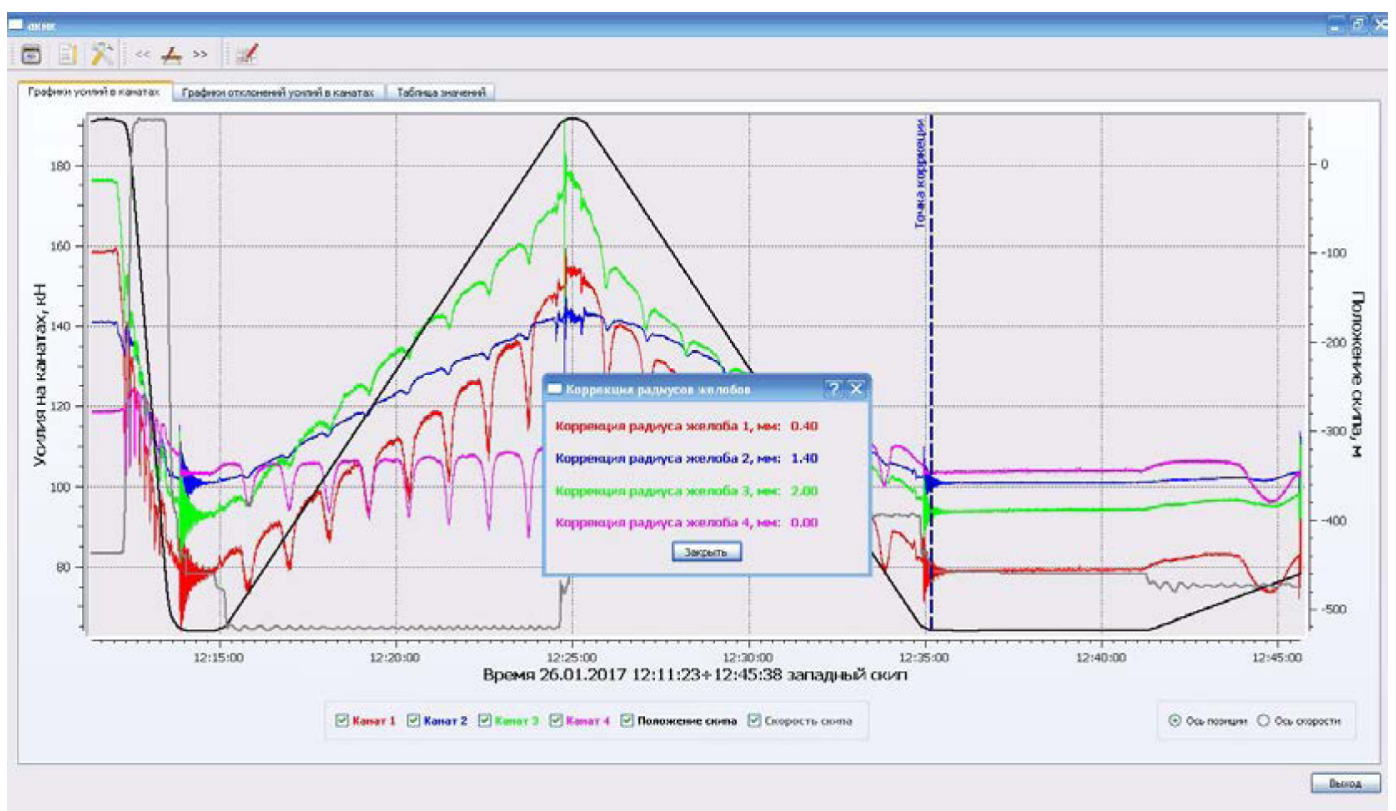

Fig. 7. The window of the program in a mode of issuing recommendations on groove creation in the rubber lining of a deflecting pulley from the side of a western skip

- when lifting a loaded skip and lowering it through the section where a rope transitions to a conical part of the drive drum, the intensity of dynamic interaction in a frontal plane increases;

- AS “ANKP” complex provides continuous monitoring of the intensity of dynamic interaction of hoisting vessels with rigid reinforcement of shafts, localization at the place of ledges at joints of guides. It performs an objective control and estimation of geometric parameters of guide profiles of mine shaft reinforcement. It also responds to any changes in profiles of a guide system, provides information on operation quality of roller guides of vessels. This allows monitoring vertical oscillations of vessels and dynamic forces in head ropes, allows identifying violations in the early stages of development of defects;

- when an empty skip is descending, an increase in dynamic intensity is applied to the beginning section of deceleration due to an abrupt break of the curve of velocity diagram;

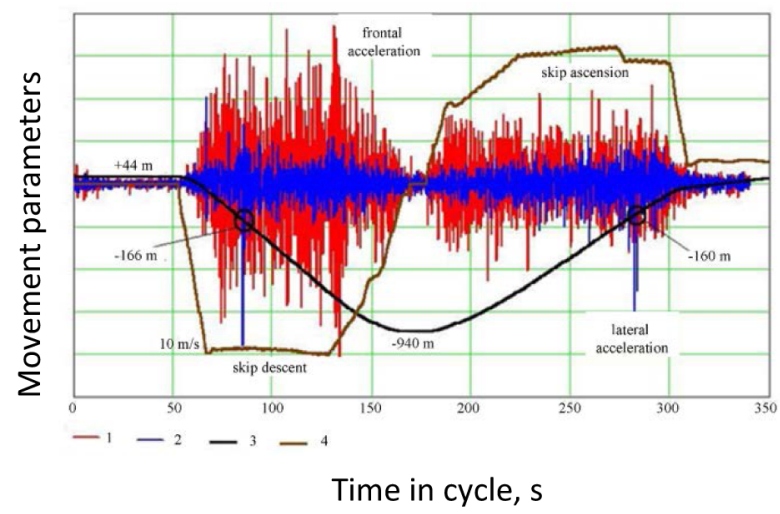

Fig. 8. Summary diagram of parameters of a skip motion:

1 - frontal acceleration, $\mathrm{m} / \mathrm{s}^{2} ; 2$ - lateral acceleration, $\mathrm{m} / \mathrm{s}^{2}$; 3 - coordinates of a vessel, $m ; 4$ - velocity of a vessel, $m / s$
- results of continuous monitoring of movement dynamics of lifting vessels are displayed in movement diagrams in real time, are recorded in the archive and can be viewed at any time;

- results of continuous monitoring can (and should) be analyzed every day by people with special training;

- use of continuous monitoring systems for smooth movement of hoisting vessels allows checking the reinforcement of vertical shafts with greater frequency.

On the basis of a controller of a driver of route commands and a speed limiter, "KFPKiOS", PJSC "Alliance-D" and M.S. Polyakov Institute of Geotechnical Mechanics of NAS of Ukraine are developing a software and hardware complex for optimal control of velocity of hoisting vessels "KOU SHPU-DNEPR".

As was shown above, the use of such a system significantly reduces dynamic loads on the reinforcement, ropes, hoisting machine, increase the permissible value of the maximum hoisting velocity, reduces cycle time, and increases the productivity of hoisting operation.

\section{Conclusion.}

1. Dynamic processes in multi-mass systems of mine hoisting machines with distributed and focused parameters in operational and transitional modes have a property of strong interconnection and cumulative strengthening of risk-forming phenomena in "hoisting vessels reinforcement" systems.

2. The cumulative effect significantly increases the risk of an emergency situation when the vessels interact with the reinforcement guides in wear conditions during long-term operation.

3. Application of means of complex automated monitoring of parameters and optimal control of operation of power units of a machine allows significant reduction of the level of dynamic loading and the risk of emergency in a shaft equipment of hoisting machines. 


\section{References.}

1. Pivnyak, G., Dychkovskyi, R., Smirnov, A. and Cherednichenko, Yu., 2013. Some aspects on the software simulation implementation in thin coal seams mining. Energy Efficiency Improvement of Geotechnical Systems, pp. $1-11$.

2. Vlasov, S. F., Babenko, V.E., Tymchenko, S.E., Kovalenko, V. L. and Kotok, V. A., 2018. Determination of rational parameters for jet development of gas hydrate deposits at the bottom of the black sea. ARPN Journal of Engineering and Applied Sciences, 13(10), pp. 3334-3339. 3. Samusya, V. I., Oksen, Y. I. and Radiuk, M. V., 2013. Heat pumps for mine water waste heat recovery. In: Annual Scientific-Technical Collection - Mining of Mineral Deposits, pp. 153-157.

4. Kyrychenko, Y., Samusia, V., Kyrychenko, V. and Goman, O., 2012. Experimental investigation of aeroelastic and hydroelastic instability parameters of a marine pipeline. Geomechanical Processes During Underground Mining - Proceedings of the School of Underground Mining, pp. 163-167. Available at: $<$ http://www. crcnetbase.com/doi/abs/10.1201/b13157-28> [Accessed 23 August 2017].

5. Shpachuk,V., Chuprynin, A., Suprun, T. and Garbuz, A., 2018. A multifactor analysis of the rail transport car that passes over a joint unevenness with respect to the phases ot its motion. Eastern European Journal of Enterprise Technologies, 1(7(91)), pp. 55-61. DOI: 10.15587/1729-4061.2018.121584.

6. Taran, I. and Klymenko, I., 2017. Analysis of hydrostatic mechanical transmission efficiency in the process of wheeled vehicle braking. Transport Problems, 12/ Special Edition, pp. 45-56. DOI: 10.20858/tp.2017.12.se.4. 7. Bazhenov, V.A., Gulyar, A.I., Piskunov, S. O. and Andrievskii, V.P., 2013. Design life assessment of the blade root of a gas turbine unit under thermomechanical loading. Strength of Materials, 45(3), pp. 329-339.

8. Franchuk, V.P., Ziborov, K. A., Krivda, V. V. and Fedoriachenko, S. O., 2018. Influence of thermophysical processes on the friction properties of wheel - rail pair in the contact area. Naukovyi Visnyk Natsionalnoho Hirnychoho Universytetu, 2, pp. 46-52. DOI: 10.29202/ nvngu/2018-2/7.

9. Trifanov, G. D., Strelkov, M.A. and Zverev, V.U., 2015. Methods for minimizing dynamic loads in ropes of mine hoisting installations, Mining magazine, 8, pp. 9295. DOI: 10.17580/gzh.2015.08.19.

10. Trifanov, G.D. and Mikriukov, A. U., 2013. Continuous dynamic control of straight reinforcement of vertical shafts, Mining equipment and electromechanics, 11, pp. 6-10. 11. Vorobel, S.V., Trifanov, G.D. and Kniazev, A.A., 2007. Dynamic examination of mine shafts hard reinforcement, Problems of complex development of mineral deposits in Perm region [online], pp. 195-201. Available at: <http://docplayer.ru/45874443-Dinamicheskoe-obsledovanie-zhestkoy-armirovki-shahtnyh-stvolov.html> [Accessed 22 November 2017].

12. Trifanov, G. D. and Mikriukov, A. U., 2014. Tests of control system for smooth movement of lifting vessel in shaft, Mining equipment and electromechanics, 12, pp. 16-23.
13. Zabolotny, K. and Panchenko, Y., 2010. Definition of rating loading in spires of multilayer winding of rubber-rope cable. New Techniques and technologies in Mining, pp. 223-229. Available at: <https://www.taylorfrancis.com/books/9780203093351> [Accessed 5 September 2017].

14. Belmas, I. V., Kolosov, D. L., Kolosov, A. L. and Onyshchenko, S. V., 2018. Stress-strain state of rubbercable tractive element of tubular shape. Naukovyi Visnyk Natsionalnoho Hirnychoho Universytetu, 2, pp. 60-69. DOI: $10.29202 /$ nvngu/2018-2/5.

15. Kolosov, D., Bilous, O., Tantsura H. and Onyshchenko, S., 2018. Stress-strain state of a flat tractivebearing element of a lifting and transporting machine at operational changes of its parameters. Solid State Phenomena, 277, pp. 188-201.

16. Pukach, P.Ya., Kuzio, I.V., Nytrebych, Z.M. and Il'kiv, V.S., 2018. Asymptotic method for investigating resonant regimes of nonlinear bending vibrations of elastic shaft. Naukovyi Visnyk Natsionalnoho Hirnychoho Universytetu, 1, pp. 68-73. DOI: 10.29202/nvngu/ 2018-1/9. 17. Loveikin, V. S. and Romasevych, Yu. O., 2017. Dynamic optimization of a mine winder acceleration mode. Naukovyi Visnyk Natsionalnoho Hirnychoho Universytetu, 4, pp. 55-61.

18. Kacalak, W., Budniak, Z. and Majewski, M., 2017. Crane stability assessment method in the operating cycle. Transport Problems, 12/4, pp. 141-151. DOI: 10.20858/tp.2017.12.4.14.

19. Bazhenov, V.A., Gulyar, A. I., Piskunov, S.O., Sakharov, A.S., Shkryl', A.A. and Maksimyuk, Yu. V., 2011. Solving linear and nonlinear three-dimensional problems of fracture mechanics by a semi-analytic finite element method. Part 1. Theoretical background and a study of efficiency of fem procedure for solving threedimensional problems of fracture mechanics. Strength of Materials, 43(1), pp. 15-24.

20. Bazhenov, V.A., Gulyar, A. I., Piskunov, S. O., Sakharov, A.S., Shryl', A.A. and Maksimyuk, Yu. V., 2011. Solving linear and nonlinear three-dimensional problems of fracture mechanics by a semi-analytic finite element method. Part 2. A procedure for computing the invariant J-integral in FEM discrete models. Strength of Materials, 43: 122. DOI: 10.1007/s11223-011-9278-9.

\section{Ризикоутворюючі динамічні процеси в ланках шахтних підйомних установок вертикальних стволів}

\author{
С. Р. Ільён ${ }^{1}$, В. І. Самуся ${ }^{2}$, Д. Л. Колосов ${ }^{2}$, \\ I. С. Ільїна $a^{2}$, C. С. Ільёна ${ }^{2}$
}

1 - Інститут геотехнічної механіки імені М. С. Полякова НАН України, м. Дніпро, Україна, e-mail: iljin_sr@ukr.net 2 - Державний вищий навчальний заклад „Національний гірничий університет”, м. Дніпро, Україна, e-mail: vsamusya@gmail.com; evolyuta@gmail.com

Мета. Оцінка ризикоутворюючих процесів при роботі підйомних установок у вертикальних стволах шахт.

Методика. Комплексний аналіз результатів теоретичних досліджень і експериментальних даних 
апаратурних вимірювань параметрів геометрії провідників, динамічної взаємодії підйомних посудин з армуванням стовбурів, діаграм швидкості руху посудин, зносу елементів армування та деформаційно-міцнісних розрахунків.

Результати. Показано, що динамічні процеси в шахтних підйомних установках у робочих і перехідних режимах мають властивість сильного взаємозв'язку й кумулятивного посилення ризикоутворюючих явищ у системах ,підйомна посудина - армування“. Кумулятивний ефект може виникати за критичного взаємовпливу процесів у різних ланках підйомної установки навіть за умов, що параметри кожного процесу не виходять за допустимі для нього межі. Це значно підвищує ризик аварійної ситуації при взаємодії посудин із провідниками армування в умовах зносу за тривалої експлуатації. Указані засоби зі зниження рівня ризику спонтанних аварій, що забезпечують підвищення безпеки роботи підйомних комплексів.

Наукова новизна. У роботі на базі комплексного аналізу електромеханічних процесів у ланках підйомних установок показано, що основними ризикоутворюючими факторами є: неплавний характер зміни швидкості підйому під час циклів спуску/ підйому посудин; зсув вантажу в посудині; розбаланс натягів головних канатів багатоканатних установок; нерівномірний за глибиною ствола знос провідників і розстрілів армування в поєднанні 3 локальними викривленнями профілів провідників і порушень параметрів їх колії. При цьому аварійно небезпечний динамічний стан системи може настати навіть у тому випадку, коли параметри супутніх процесів знаходяться в допустимих межах, встановлених діючою нормативною документацією.

Практична значимість. Отримані результати дозволяють при експлуатації підйомних установок і їх експертному обстеженні комплексно оцінювати технічний стан систем „підйомна машина - канати - посудини - армування" та встановлювати об'єктивні причини виникнення аварійних ситуацій і їх передумови, розробити рекомендації, що попередять перевищення допустимого ризику в залежності від умов експлуатаціі.

Ключові слова: шахтна підйомна установка, армування шахтного стовбура, система „посудина - армування", шахтні провідники, натяг шахтних канатів

\section{Рискообразующие динамические процессы в звеньях шахтных подъемных установок вертикальных стволов}

\section{С. Р. Ильин ${ }^{1}$, В. И. Самуся², Д. Л. Колосов ${ }^{2}$, И. С. Ильина ${ }^{2}$, С. С. Ильина ${ }^{2}$}

1 - Институт геотехнической механики имени. Н. С. Полякова НАН Украины, г. Днепр, Украина, e-mail: iljin_ sr@ukr.net

2 - Государственное высшее учебное заведение „Национальный горный университет”, г. Днепр, Украина, e-mail: vsamusya@gmail.com; evolyuta@gmail.com
Цель. Оценка рискообразующих процессов при работе подъемных установок в вертикальных стволах шахт.

Методика. Анализ результатов теоретических исследований и экспериментальных данных аппаратурных измерений параметров геометрии проводников, динамического взаимодействия подъемных сосудов с армировкой стволов, диаграмм скорости движения сосудов, износа элементов армировки и деформационно-прочностных расчетов.

Результаты. Показано, что динамические процессы в шахтных подъемных установках в рабочих и переходных режимах имеют свойство сильной взаимосвязи и кумулятивного усиления рискообразующих явлений в системах „подъемный сосуд - apмировка“. Кумулятивный эффект может возникать при критическом взаимовлиянии процессов в различных звеньях подъемной установки даже при условии, что параметры каждого процесса не выходят за допустимые для него границы. Это значительно повышает риск аварийной ситуации при взаимодействии сосудов с проводниками армировки в условиях износа при длительной эксплуатации. Указанные средства по снижению уровня риска спонтанных аварий, обеспечивают повышение безопасности работы подъемных комплексов.

Научная новизна. В работе на базе комплексного анализа электромеханических процессов в звеньях подъемных установок показано, что основными рискообразующими факторами являются: неплавный характер изменения скорости подъема во время циклов спуска/подъема сосудов; смещение груза в сосуде; разбаланс натяжения главных канатов многоканатных установок; неравномерный по глубине ствола износ проводников и расстрелов армировки в сочетании с локальными искажениями профилей проводников и нарушений параметров их пути. При этом аварийно опасное динамическое состояние системы может наступить даже в том случае, когда параметры сопутствующих процессов находятся в допустимых пределах, установленных действующей нормативной документацией.

Практическое значение. Полученные результаты позволяют при эксплуатации подъемных установок и их экспертном обследовании комплексно оценивать техническое состояние систем „подъемная машина - канаты - сосуды - армировка“ и устанавливать объективные причины возникновения аварийных ситуаций и их предпосылки, разработать рекомендации, которые предупредят превышение допустимого риска в зависимости от условий эксплуатации.

Ключевые слова: шахтная подъемная установка, армировка шахтного ствола, система „сосуд-армировка", шахтные проводники, натяжение шахтных канатов

Рекомендовано до публікації докт. техн. наук С.О.Кириченком. Дата надходження рукопису 08.10.17. 